\title{
О СТАРОМ ПО-НОВОМУ: ФУНКЦИОНАЛЬНОЕ ИСПОЛЬЗОВАНИЕ ОБРАЗА БАБЫ-ЯГИ В СОВРЕМЕННОМ ПУБЛИЧНОМ ДИСКУРСЕ
}

\author{
ЖАННА СЛАДКЕВИЧ \\ Гданьский университет \\ Филологический факультет \\ Кафедра прагматики коммуникации и лингводидактики \\ ул. Вита Ствоша 51, 80-308 Гданьск \\ e-mail: filzs@ug.edu.pl \\ (получено 11.09.2017; принято 27.09.2017)
}

\section{Abstract \\ A new take on an old concept: functional use of the image of Baba Yaga in contemporary public discourse}

The article is devoted to the functional use of the image of Baba Yaga in various communicative spaces, marked by different pragmatic goals. The key mythological and fairy-tale characters are in demand in modern public discourse. Numerous authors use these images due to their high cultural significance for the society, their high "recognizability", as well as the rich pragmatic potential of the images themselves. The author considers the main areas of use of Baba Yaga's image: political and social caricature, marketing space (advertising of natural cosmetics, gastronomy, food products, services), educational sphere.

\section{Key words}

Baba Yaga, modern public discourse, political caricature, commercial advertising, dual nature of the image. 


\section{Реюме}

Данная статья посвящена рассмотрению функционального использования образа Бабы-Яги в различных коммуникативных пространствах, отмеченных разными прагматическими целями. Ключевые мифологические и сказочные персонажи востребованы в современном публичном дискурсе. Обращение авторов к этим образам обусловлено их высокой культурной значимостью для социума, высокой «узнаваемостью» данного культурного продукта, а также богатым прагматическим потенциалом самих образов. Автор рассматривает основные области использования образа Бабы-Яги: политическая и социальная карикатура, маркетинговое пространство (реклама натуральной косметики, гастрономических объектов, продуктов питания, сферы услуг); образовательная сфера.

\section{Ключевые слова}

Баба-Яга, современный публичный дискурс, политическая карикатура, коммерческая реклама, двойственная природа образа.

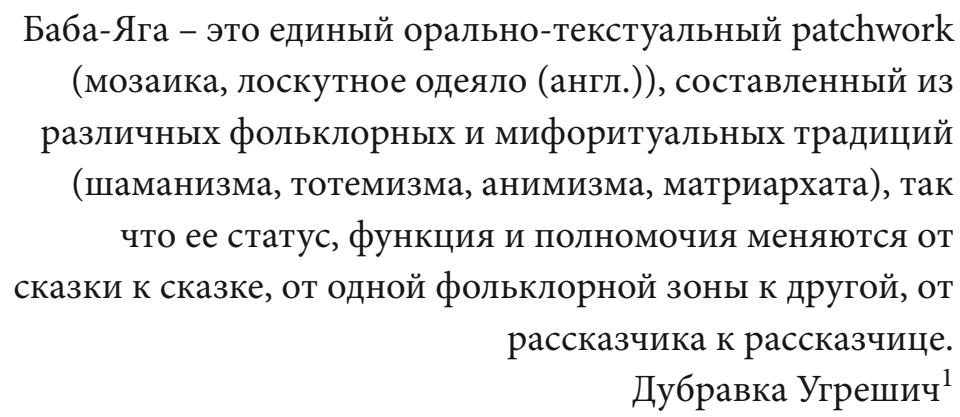

На протяжении столетий загадочный и неоднозначный образ Бабы-Яги вдохновлял сказочников, фольклористов, кинематографистов, аниматоров, сценаристов, художников на создание традиционных и новых ее воплощений в различных видах искусства. Современный публичный дискурс также не обошел стороной этот многогранный персонаж. Данная статья посвящена прагматико-концептуальным трансформациям одного из фундаментальных образов славянской демонологии - Бабы-Яги - в политической, социальной и маркетинговой сферах.

\section{Традиционная ипостась Бабы-Яги. Специфика персонажа}

Баба-Яга - это существо демоническое, чародейка, ведунья, наделенная магической силой, т.е. некая квинтэссенция древнеславянских представлений о ведьмах.

1 Д. Угрешич. Снесла Баба Яга яичко. Пер. с серб-хорв. Л. Савельевой. Москва: Эксмо, с. 329. 
Среди исследователей нет единогласия в отношении э т и м о лог и и и м е н и рассматриваемого персонажа. В славянских языках лексемы «яга» и ее производные связаны с понятием опасности, мучений и ужаса ${ }^{2}$. Так, М. Фасмер возводит имя Яга к праславянскому (j)ega, рефлексами которого являются сербское слово језа 'ужас', језив 'опасный', словенское јеza 'гнев', јеziti 'сердить', чешское jezinka 'лесная ведьма', польское jędza 'ведьма, злая баба'ㄱ и др. Существует и иная трактовка, по которой имя Бабы-Яги связано с названием определённого предмета - «халата с откладным, в четверть, воротником», согласно Очеркам Берёзового края (1857) Николая Абрамова (аналогичное толкование дает и словарь В.И. Даля $)^{4}$.

Кроме имени, на древнейшее происхождение персонажа указывает факт наличия многочисленных межкульт урных дв ойников Бабы-Яги: Германия имеет Фрау Холле, итальянцы Бефану, а венгры Богоркань. В кельтской мифологии аналогичной Бабе-Яге фигурой может быть Черная Аннис, практически идентичная со своим славянским альтер-эго, с той разницей, что местом ее обитания являются пещеры ${ }^{5}$.

В фольклоре сербов, хорватов, словенцев, македонцев, черногорцев есть старое страшило женского рода - Баба Рога, Баба Era, Гвоздензуба. (...) У болгар вместо Бабы Яги имеется Горная мать, которая вызывает бессонницу у маленьких детей. (...) Румынская Мамападуреи (Мума падурии) живет в лесу, в избушке на птичьих ногах. Избушка окружена изгородью, на которую насажены человеческие черепа. Она крадет маленьких детей и превращает их в деревья. (...) В венгерских фольклорных легендах живет Васорру баба - старая женщина с железным носом, свисающим почти до самых колен. Васорру баба любит тестировать молодых героев или героинь и, если те оказываются недостаточно любезными по отношению к ней, может превратить их в какое-нибудь животное или в камень. Рагана (по-литовски regeti означает знать, видеть, предвидеть; a ragas - это рог, полумесяц) - литовская мифологическая злодейка. (...) Рагана связана со смертью и воскресением, т. е. регенерацией ${ }^{6}$.

Примеры можно продолжать, причем не только на территории Европы, но и Африки, Азии, Латинской Америки, и все же отметим, что традиционный образ русской Бабы-Яги имеет свою специфику, характеризуется выразительной амбивалентностью, даже полярностью черт и поступков. Так, Ю.С. Степанов отмечает, что с одной стороны, Яга - «баба», «женщина», с другой - воплощение негативных черт различных мифологических героев ${ }^{7}$.

2 В. Кокорин. Баба-Яга. [Online:] <https://sites.google.com/site/kokorinva/Home/b/baba-aga> (28.08.2017).

3 М. Фасмер. Яга. [Online:] <https://vasmer.lexicography.online/\%D1\%8F/\%D1\%8F\%D0\%B3\%D $0 \% \mathrm{~B} 0>(04.09 .2017)$.

4 В. Кокорин. Баба-Яга...; Даль. Словарь Даля. 2012. [Online:] <https://slovar.cc/rus/dal/582119. html> (04.09.2017).

5 D. Winiarski. Demony Leśne. Baba Jaga. [Online:] <https://slowianskibestiariusz.pl/bestiariusz/ demony-lesne/baba-jaga/> (02.09.2017).

6 Д. Угрешич. Снесла Баба Яга яичко..., с. 422-430.

7 Ю.С. Степанов. Константы: словарь русской культуры: опыт исследования. Москва: Школа «Языки русской культуры», 1997, с. 89-91. 
В народном сознании запечатлен поражающий воображение в нешн и й о бл и к Бабы-Яги как уродливой столетней старухи, растрепанной и длинноносой, отличающейся наличием костяной ноги и безошибочно распознающей «дух» человечий. По причине костеногости Баба-Яга в русских сказках не ходит: она либо летает в ступе, погоняя ее пестом и заметая след помелом, либо лежит, растянувшись из угла в угол, словно в гробу (Лежит Баба-Яга, костяная нога из угла в угол, нос в потолок врос; Баба-Яга из угла в угол перевертывается: одной губой пол стирает, а носом трубу затыкает), т.е. проявляет себя как мертвец.

Не случайно по одной из версий, Баба-Яга - это п р о в о д н и к в п о т ус т о ронни й м и $\mathrm{p}^{8}$. Живет в дремучем лесу на границе миров живых и мертвых, в «тридевятом царстве», где-то «за тридевять земель, за огненной рекой», где «нет ни стежечки, ни дорожечки». Такое место в мифологическом сознании воспринимается как потусторонний мир. Дом старухи огорожен тыном, на каждой из тычинок которого торчит по голове, и только на одной тычинке головы нет. Сама знаменитая избушка на курьих ножках - словно проходная в этот мир, поскольку войти в нее нельзя, пока она, после произнесенного заклинания, не повернется к лесу задом. В древности умерших хоронили в домовинах - домиках, расположенных над землей на высоких пнях с выглядывающими из-под земли корнями, отверстием к лесу. Хоронили ногами к выходу, что, вероятно, послужило источником выражения Баба-Яга костяная нога. В.Я. Пропп обращает внимание на важную деталь: в русских сказках Яга топит баню и выпаривает героя, совершая таким образом ритуальное омовение, после чего кормит пришедшего обрядовым угощением, которое «отверзает уста умершего» и позволяет ему попасть в тридесятое царство9. Таким образом, Баба-Яга, стоящая на границе миров живых и мертвых, служит проводником, помогающим герою проникнуть в потусторонний мир благодаря совершению определенных ритуалов. Более того, во многих сказках этому персонажу свойственно людоедство, что соотносит образ опасной старухи с мифологическими представлениями о персонифицированной смерти.

По другой версии, прототип Бабы-Яги - в ед ун ь и, з н ах арки, нелюдимые женщины-целительницы и собирательницы трав, которые лечили людей и часто селились в лесу, вдали от деревни. Ягой-бабой (егибовой, егибицей) крестьяне некоторых районов России именовали сходную с рассматриваемым персонажем по облику и занятиям колдунью ${ }^{10}$. Обычай же Бабы-Яги поджаривать детей в печи на лопате напоминает обряд «перепекания» младенцев, «недозревших» в материнском чреве, т.е. больных рахитом или атрофией: ребенка заворачивали в «пеленку» из ржаного теста, клали на деревянную хлебную лопату

8 В.П. Аникин. К мудрости ступенька. О русских песнях, сказках, пословицах, загадках, народном языке. Очерки. Москва: Детская литература, 1982, с. 41-44.

9 См. подробнее: В.Я. Пропп. Таинственный лес. [В:] В.Я. Пропп, Исторические корни волшебной сказки. Ред. и комм. И.В. Пешкова, Москва: Лабиринт 2000, с. 36-89.

10 В.В. Иванов, Н.В. Топоров. Баба Яга. [В:] Славянская мифология. Энииклопедический словарь, Москва: Эллис лак, 1995, с. 45. 
и трижды всовывали в теплую печь, после чего разворачивали, а тесто отдавали на съедение собакам ${ }^{11}$.

Исследователи усматривают связь образа Бабы-Яги (хозяйки леса) с тотемным животным, которому поклонялись и просили об обеспечении успешной охоты. Более того, этот образ восходит к дохристианским представлениям об устройстве мира и матриархальном укладе жизни - Баба-Яга рассматривается как жрица-родонача льни ца, прародительница, старшая женщина в роду, берегиня ${ }^{12}$ рода, хранительница его жизненного пространства, обычаев и традиций ${ }^{13}$. Мудрая жрица-ведунья в древности распоряжалась не только обрядом захоронения, но и обрядом инициации ${ }^{14}$, т.е. посвящения мальчиковподростков в полноправные члены общины. Обряд сопровождался телесными повреждениями, что также способствовало трансформации образа ведуньи в образ страшной и кровожадной ведьмы, которая похищает детей ${ }^{15}$.

Таким образом, Баба-Яга - это многоликий образ, впитавший в себя множество мифов, символов, обрядов славянского прошлого. Прежде чем стать сказочным персонажем, Баба-Яга была существом мифологическим. Образ Бабы-Яги в преданиях славян изначально не был отрицательным, однако по мере же распространения на Руси христианства Бабе Яге стали приписываться отрицательные черты: «Баба Яга изначально - прародительница, очень древнее положительное божество славянского пантеона, хранительница (если надо воинственная) рода и традиций, детей и околодомашнего (часто лесного) пространства. В период насаждения христианства всем языческим богам и божествам, духам, в том числе и оберегавшим людей (берегиням), придавались злые,

11 В. Пономарева. Обряд «перепекания» ребенка: на лопату и в печь. [Online:] <http://telo.by/ massage/obryad_perepekaniya_rebenka/> (09.09.2017).

12 В такой нетипичной для западного дискурса ипостаси предстает Баба-Яга в интерпретация Томаша Багинского в цикле «Польские Легенды Аллегро» (Legendy Polskie. Film Jaga. Allegro, 2015. [Online:] <https://www.cda.pl/video/1169502e8>). Яга - это молодая женщина-воительница, страстно желающая восстановить естественный порядок вещей, спасти человечество. Сценарист Блажей Дзиковски (Błażej Dzikowski) создал персонаж, который ломает стереотипное представление о Бабе-Яге как старухе, живущей в избушке на курьих лапках и любящей есть детей. Молодая Яга (Katarzyna Pośpiech) любой ценой хочет вернуть потерянный мир, в котором дети бегали босиком по лугам, а воздух был кристально чистым. Для осуществления этого благородного в ее представлении хаоса, она убегает из ада, которым руководит самовлюбленный карьерист - дьявол Борута (Tomasz Drabek).

13 В.В. Иванов, Н.В. Топоров. Баба Яга. [В:] Славянская мифология. Энциклопедический словарь. Москва: Эллис лак, 1995, с. 45; Ведический образ Бабы Яги. [Online:] <http://newcivilization.mirtesen.ru/blog/43840501133/vedicheskiy-obraz-babyi-yagi> (01.09.2017).

14 В.Г. Балушок. Инициации древних славян. [Online:] <http://svitk.ru/004_book_book/1b/27_ baluhok-iniciacii_drevnih_slovyan.php> (06.09.2017).

15 Существуют и более экзотические версии происхождения образа Бабы-Яги. Наиболее известные из них это гипотеза исследователя А. Подъяпольского об индийском генезисе персонажа: Баба-Яга - это трансформированное «баба-йога», т.е. «учитель-йог» и теория инопланетного происхождения Бабы-Яги, разработанная Ю. Росциусом (Е.Е. Чистякова. Истоки происхождения образа Бабы Яги. 2017. [Online:] <https://nsportal.ru/ap/library/literaturnoe-tvorchestvo/2017/04/29/istoki-proishozhdeniya-obraza-baby-yagi> (10.09.2017)). 
демонические черты, уродливость внешнего вида и характера, злые намерения. Так, языческая строгая прародительница была превращена в злобного демона, которым пугают маленьких детей» ${ }^{16}$. В русских волшебных сказках отражена двойственность образа Бабы-Яги: она может быть и помощницей, и демономвредителем.

\section{Ипостаси Бабы-Яги в современном публичном дискурсе}

В настоящее время можно констатировать расширение пространства волшебной сказки и ее экспансию в смежные творческие сферы. Базовые мифологические и сказочные образы оказались весьма востребованными в современном публичном коммуникативном пространстве. Обращение авторов к этим образам обусловлено, в первую очередь их высокой культурной значимостью для социума, высокой «узнаваемостью» данного культурного продукта, а также богатым прагмакоммуникативным потенциалом самих образов.

Рассмотрим наиболее продуктивные ипостаси Бабы-Яги, реализуемые в нескольких коммуникативных пространствах, отмеченных разными прагматическими целями. Можно выделить следующие области использования данного образа: политическая и социальная карикатура; маркетинговое пространство (реклама натуральной косметики, гастрономических объектов, продуктов питания, сферы услуг); образовательная сфера и культурно-просветительская деятельность, литературное и кинематографическое творчество. Будучи ограниченными рамками статьи, рассмотрим подробнее вариации образа Яги в современной карикатуре и рекламе.

\section{Образ Бабы-Яги в социально-политической карикатуре}

Поликодовые, вербально-визуальные жанры ${ }^{17}$, как к а р и кат ура (а также реклама, этикетка, анимация, видеоролик, сайт с иллюстрациями), содержащие иконическую часть, характеризуются огромным воздействующим потенциалом, поскольку «визуальные образы обладают бо́льшей сенситивностью, чем

16 А. Баженова. Солнечные боги славян. [Online:] <http://www.lomonosov.org/article/solar_ gods_slavs.htm> (10.09.2017).

17 См. об этом: Е.Е. Анисимова. Паралингвистика и текст (к проблеме креолизованных и гибридных текстов). «Вопросы языкознания» 1992, № 1, с. 71-78; А.А. Бернацкая. К проблеме «креолизации» текста: история и современное состояние. «Речевое общение: Специализированный вестник». Ред. А.П. Сковородников. Красноярск 2000. Вып. 3 (11), с. 104-110; Л.С. Большакова. О содержании понятия «поликодовый текст». «Вестник СамГУ» 2008, № 4 (63), с. 19-24; М.А. Ищук. Гетерогенный текст: функции его составляющих. «Вестник ТвГУ: Серия Филология». Выпуск: Лингвистика и межкультурная коммуникация 2008, № 13, с. 176-182; Ю.А. Сорокин, Е.Ф. Тарасов. Креолизованные тексты и их коммуникативные функизии. [В:] Оптимизация речевого воздействия. Москва: Москва 1990, с. 180-186; Ż. Sładkiewicz. Społeczeństwo „OKA” i tekst wielokodowy (na przykładzie rosyjskiej satyry politycznej), „Przegląd Rusycystyczny” 2014, № 3 (147), c. 111-124. 
устное или письменное слово» ${ }^{18}$, они наглядны, напрямую влияют на психику человека и передают «месседж» в ярких и запоминающихся образах. Исследователи креолизованных текстов отмечают их высокую интертекстуальную плотность, т.е. обыгрывание прецедентных феноменов. Прецедентными называются явления: 1) имеющие сверхличностный характер, 2) актуальные в познавательном и эмоциональном плане, 3) обращение к которым регулярно возобновляется в речи представителей лингвокультурного сообщества ${ }^{19}$. Частое обыгрывание прецедентных феноменов в социально-политической карикатуре обусловлено ее спецификой как смехового жанра, базирующегося на переиначивании и травестировании устойчивых, «авторитетных» для определенного контингента культурных форм.

Е.А. Артемова, исследовавшая карикатуру как жанр политического дискурса, выделяет 4 вида пресуппозиций, детерминирующих понимание реципиентом смысла сообщения ${ }^{20}:$ 1) экстралингвистическая, т.е. знания в области культуры, фольклора, литературы; 2) политическая - знание политических событий, визуальное опознавание политических личностей, партий, их символики; 3) логическая - представление о натуральных отношениях между событиями; 4) лингвистическая - знание особенностей языка, его графических и суперсегментивных средств, актуальных для порождения, выражения и восприятия имплицитной информации.

Итак, в карикатуре дается «некий эквивалент действительному событию или ситуации, но с переносом на иную изобразительную плоскость. “Картинка” становится новым означающим для исходного означаемого (события, ситуации)» ${ }^{21}$. В этой связи понятие прецедентности становится ключевым, поскольку «узнаваемость» визуального образа является основополагающей для жанра карикатуры.

Традиционное представление о Яге как старой отвратительной ведьме, с большим носом и костяной ногой, живущей в глухом лесу в избушке на курьей ножке, любящей полакомиться человечиной, позволяет широко использовать образ Бабы-Яги в политической карикатуре с целью демонизации идеологического оппонента. Следует отметить, что в российском сатирическом пространстве этот персонаж воплощают собой Юлия Тимошенко 22 (с наибольшей частотностью), Дженнифер Псаки, Кэтрин Эштон, Ирина Фарион (рис. 1-3):

18 Порозов Р.Ю. Визуальное как доминанта современной культуры. «Политическая лингвистика». Ред. А.П. Чудинов. Екатеринбург 2011. Вып. 2 (36), с. 221.

19 Ю.Н. Караулов. Русский язык и языковая личность. Москва: Наука, 1987, с. 216.

20 Е.А. Артемова. Карикатура как жанр политического дискурса. Диссертация на соискание научной степени кандидата филолологических наук. Волгоград 2002. [Online:] <http://dibase. ru/article/05042010_artemova_evgenija_aleksandrovna_4478/1> (23.03.2017).

21 И.Н. Куклина. Явления фразеологизации и дефразеологизации в языке современной прессы. Диссертация на соискание научной степени кандидата филологических наук, Москва: МГОУ 2006, с. 118.

22 Анекдот из сети в тему - см.: [Online:] <http://pikabu.ru/story/bednaya_babayaga_3329875> (28.08.2017):

Как-то раз встретились Мальвина, Дюймовочка и Баба-Яга и давай хвастать: 


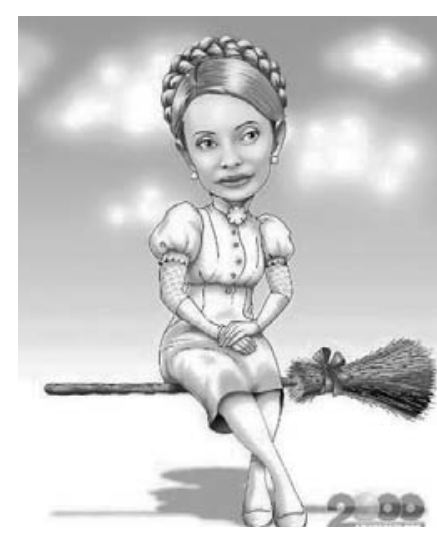

Рис. 1. Ю. Тимошенко

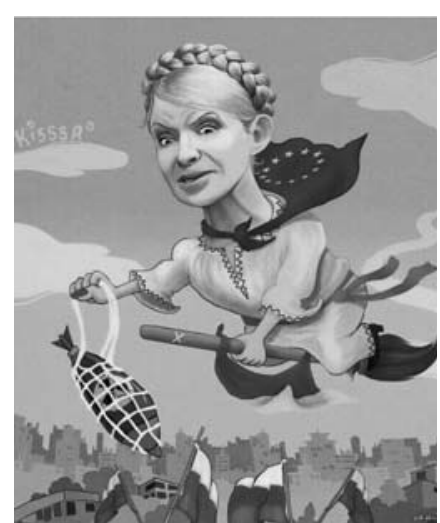

Рис. 2. Ю. Тимошенко

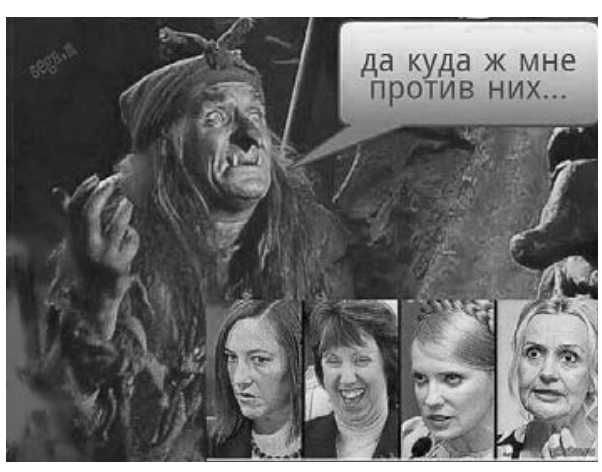

Рис. 3. Яга: Да куда ж мне против

Приведенные примеры показывают, что при использовании сказочного образа в политической карикатуре (шарже, демотиваторе) используется несколько базовых приемов, таких как:

- комическое заострение черт внешности и характера;

- усиление внешнего сходства за счет визуального сопоставления о пре де ленн ог о ракурса снимка политического субъекта и его сказочного прототипа:

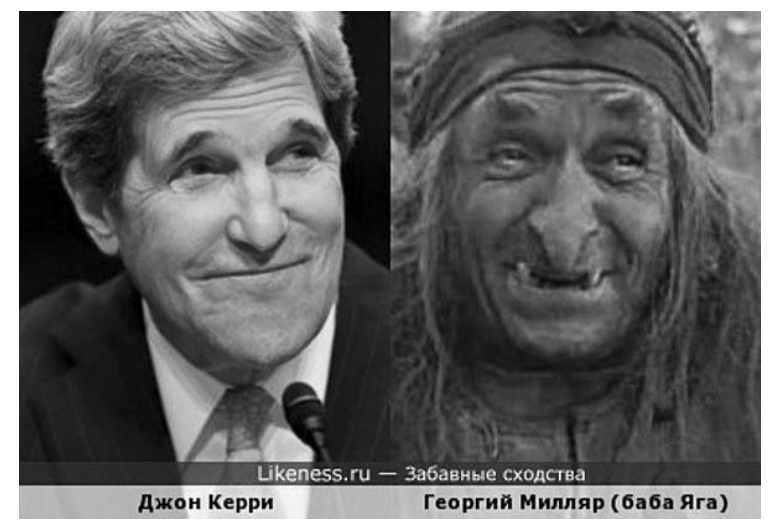

Рис. 4. Дж. Керри - Баба Яга

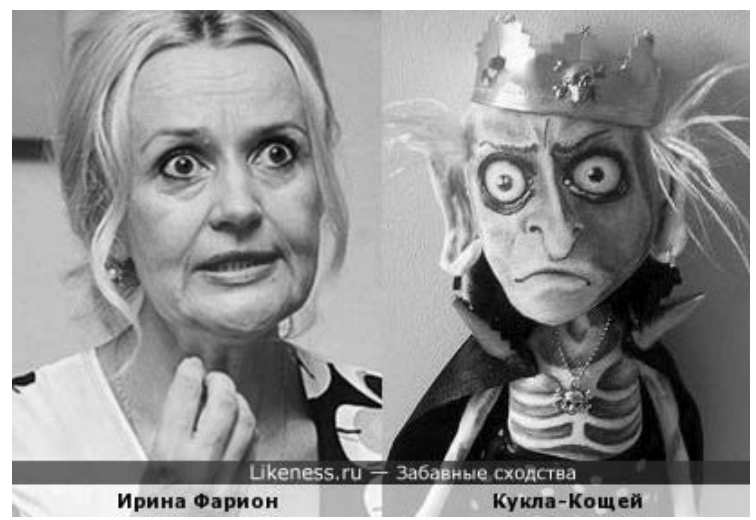

Рис. 5. И. Фарион - Кощей Бессмертный

- Я самая Красивая, - говорит Мальвина.

- А я самая Маленькая! — отвечает Дюймовочка.

А Баба-Яга угрожающе обеим:

- А я самая Жестокая и Коварная!!!

Тут вдруг возник перед ними Домик Правды!

Зашла в него Мальвина и выбежала, рыдая:

- Я не самая Красивая! Белоснежка Красивей меня!

Дальше Дюймовочка. Вышла со слезами и говорит:

- Я не самая Маленькая, Мальчик-с-пальчик Меньше меня!

Залетает на метле в домик Баба-Яга... через полчаса только выходит растерянно, чешет плешь и бормочет:

- Чёрт, я так и не поняла ни черта. Кто такая Юлия Тимошенко??? 

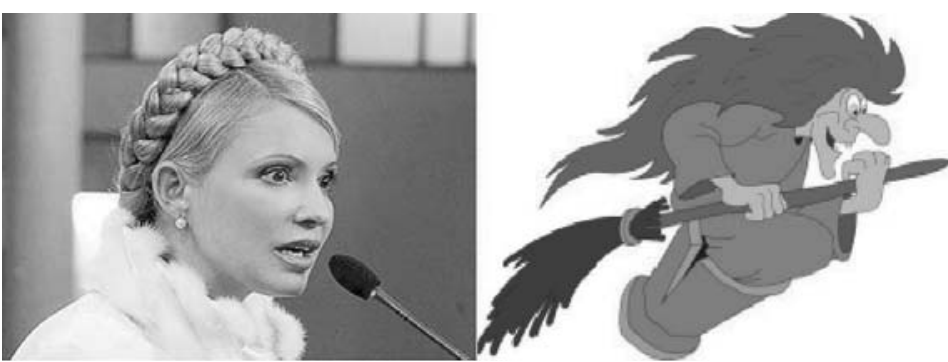

Рис. 6. Ю. Тимошенко - Баба Яга

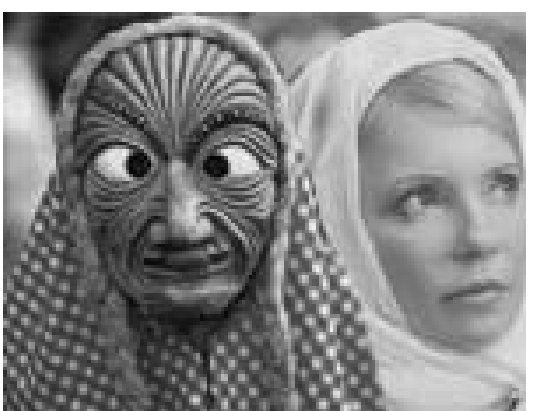

Рис. 7. Ю. Тимошенко - Баба Яга

- использование прецедентных высказываний. Так, например, Баба Яга против - это крылатая цитата из одноименного советского мультфильм 1979 года, выпущенного студией «Союзмультфильм» к летним Олимпийским играм 1980 года. Сюжет истории заключается в том, что Медвежонок Миша выбран талисманом Олимпиады, однако Баба-Яга вместе со Змеем Горынычем и Кощеем Бессмертным стремятся помешать ему сначала попасть на Олимпиаду, а затем и участвовать в ней. Использование данной цитаты в карикатуре способствует трансформации визуального ряда, исходным фреймом для которого является серьезный политический дискурс, в новый фрейм - комический, как в карикатурах, представляющих Виталия Чуркина в ООН (рис. 8), писательницу и журналиста Юлию Латынину (рис. 9) или блок Юлии Тимошенко (рис. 10):

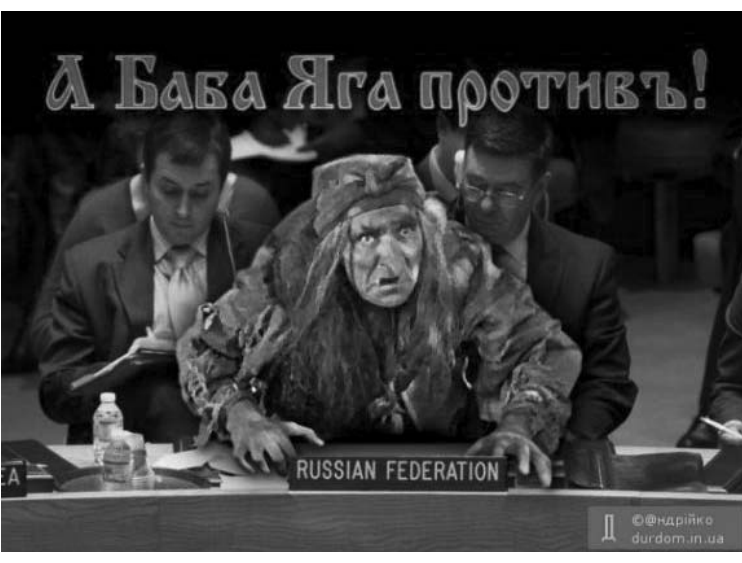

Рис. 8. В. Чуркин против!

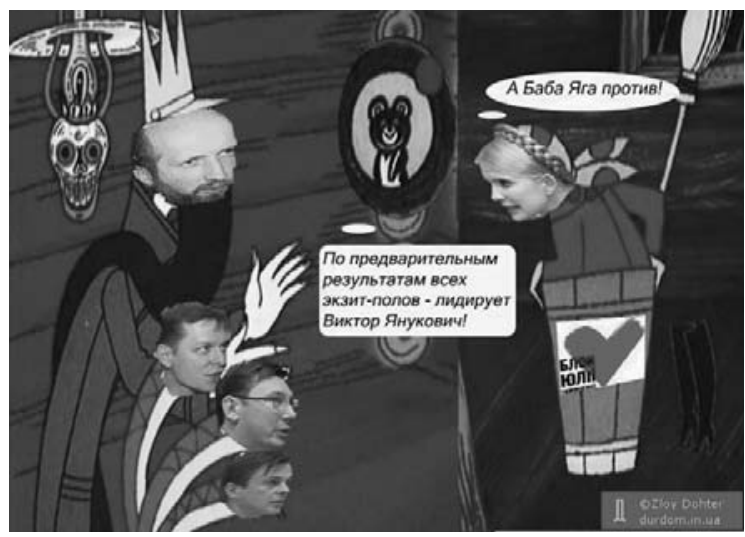

Рис. 10. Блок Ю. Тимошенко против!

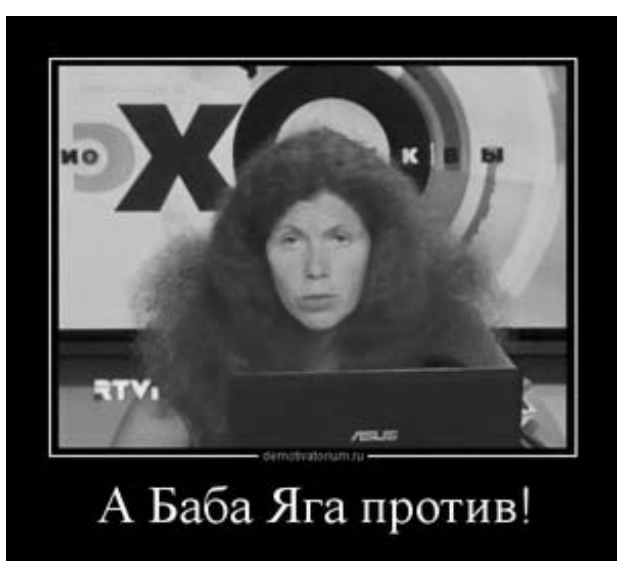

Рис. 9. Ю. Латынина против!

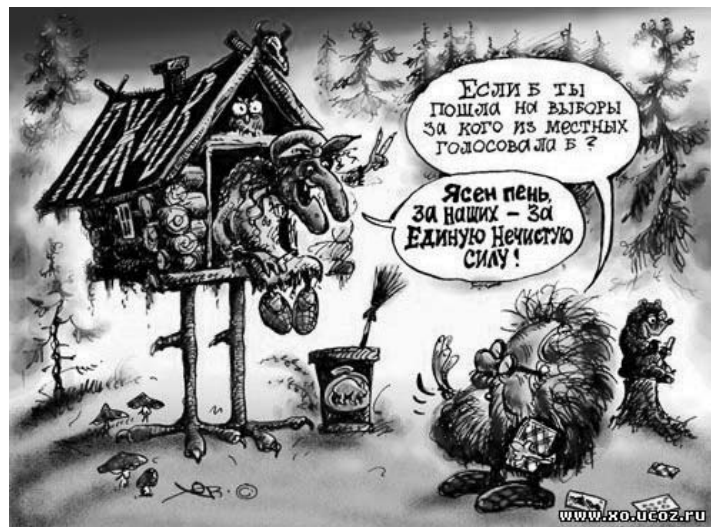

Рис. 11. За Единую Нечистую Силу! 
Оценочные трансформации названий партий, выполненные в рамках сказочной метафорической модели, не нарушают узнаваемости референтного политического субъекта, обозначенного в тексте карикатуры (рис. 11):

Леший: - Если б ты пошла на выьборы, за кого из местных голосовала б?

Баба-Яга: - Ясен пень, за наших - за Единую Нечистую Силу!

Весьма частотно использование образа Бабы-Яги в социальной карикатуре. Несмотря на то, что в эпоху высоких технологий Баба-Яга как карикатурный персонаж пытается идти в ногу со временем, пользуясь компьютером, спутниковой антенной и электродвигателем (рис. 12-14), в современной российской действительности ей пришлось столкнуться с рядом социальных проблем: материальных, медицинских, транспортных и имущественных.

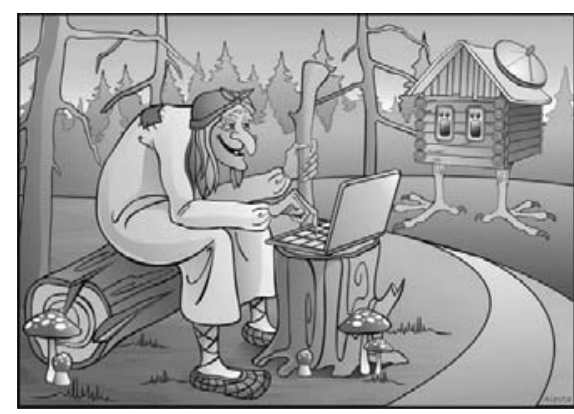

Рис. 12. Баба-Яга и техника

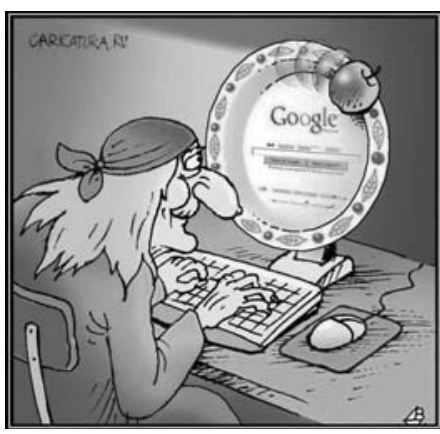

Рис. 13. Google

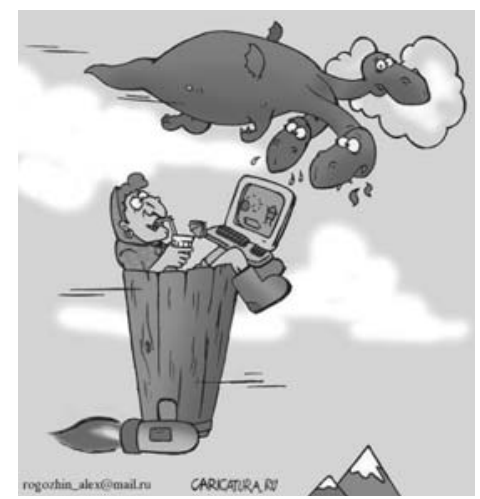

Рис. 14. В век высоких технологий

Наиболее популярные социальные сюжеты с образом Бабы-Яги можно разделить на несколько групп: Яга и недвижимость, Яга и транспорт, Яга и визиты к врачу (в т.ч. беременность). В карикатуре Баба-Яга вынуждена искать источник доходов, стать в очередь на жилье, отстаивать право на свое имущество перед риелторами, продавать или сдавать в аренду избушку, обращаться в ЖЭС, в эпоху кризиса варить себе похлебку из курьих ножек, вызывать механика к избе или ступе, терять сбережения, отданные в банк, объясняться с полицией по поводу столкновения с городским транспортом, обращаться к врачу, принимать новые препараты, хоронить избушку, павшую от птичьего гриппа и т.п. (рис. 15-20)

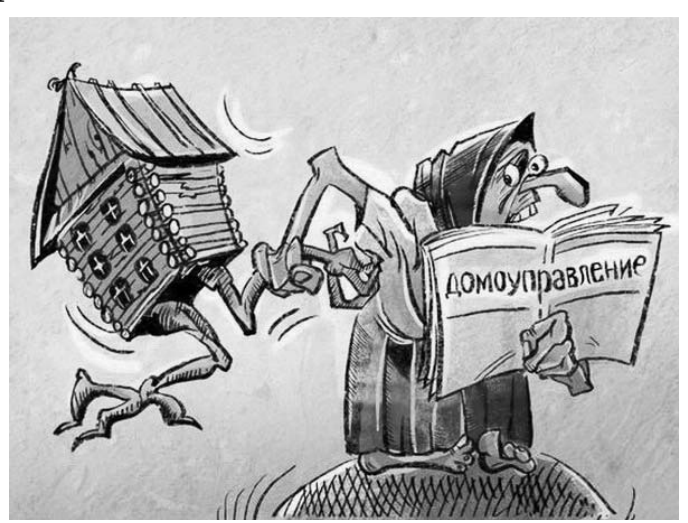

Рис. 15. Домоуправление

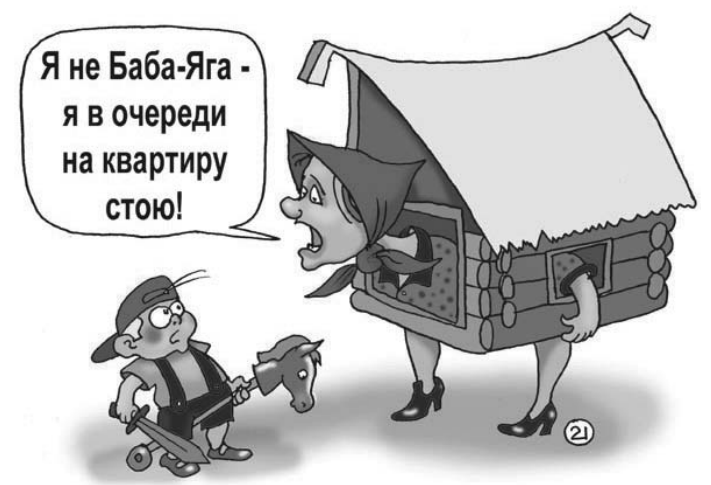

Рис. 16. В очереди на квартиру 


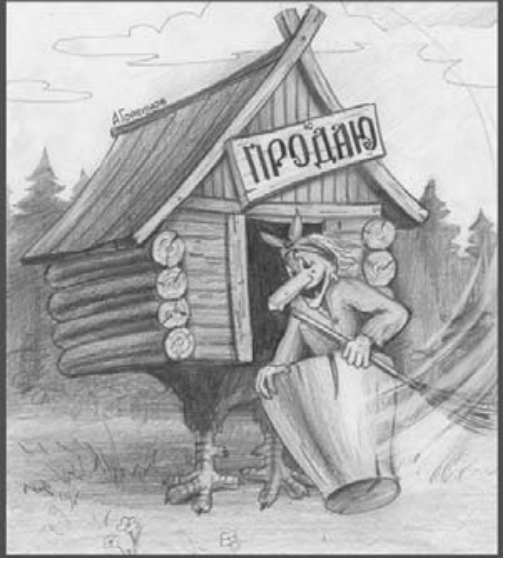

Рис. 17. Продаю

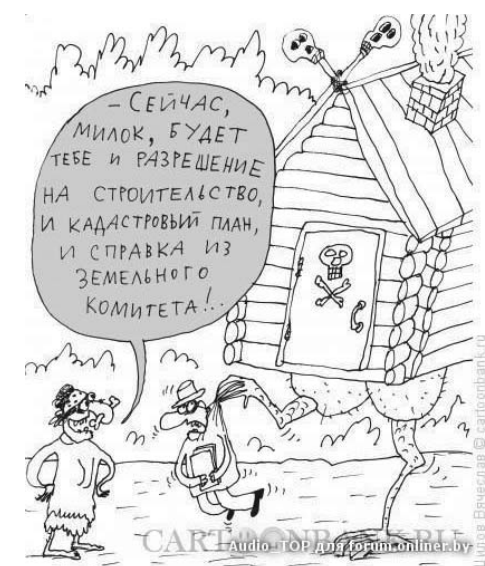

Рис. 18. Риелтор

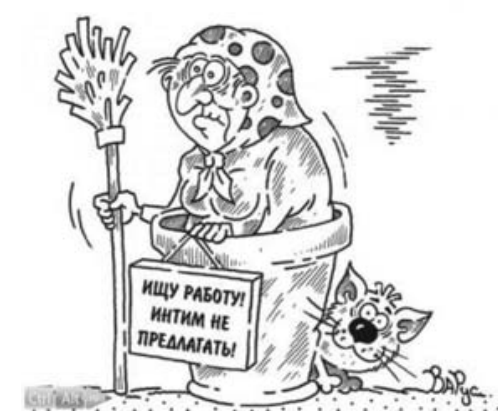

Рис. 19. Ищу работу
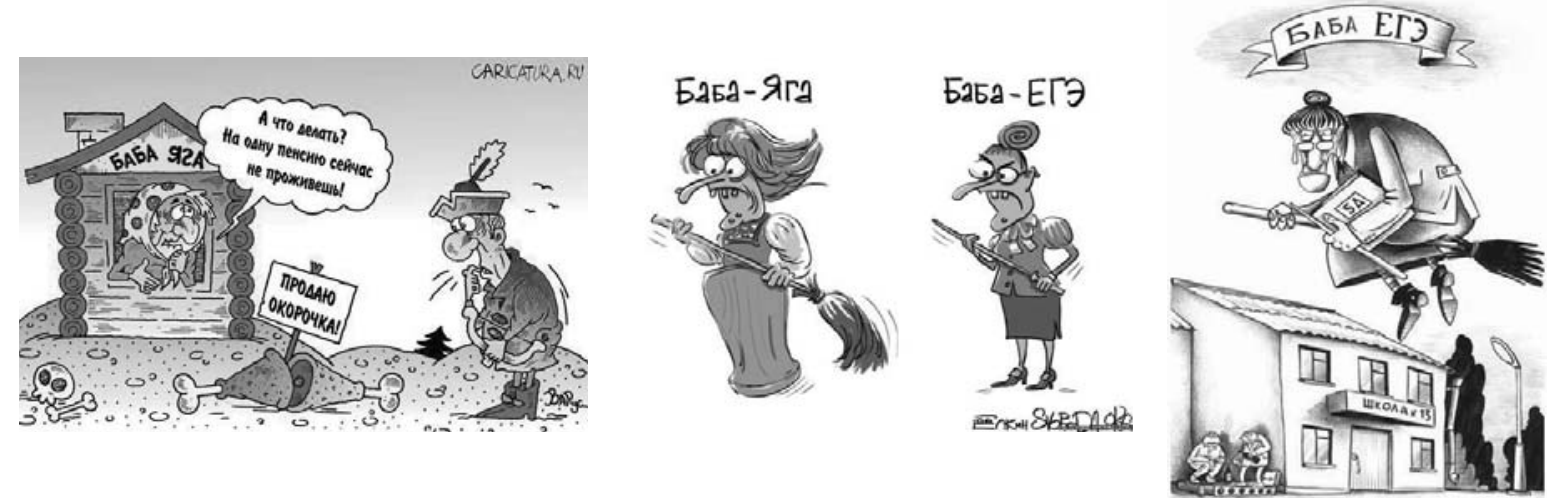

Рис. 20. На пенсию не проживешь

Рис. 21. Яга - ЕГЭ

Рис. 22. Баба ЕГЭ

Фонетическое созвучие Яга - ЕГЭ позволяет широко использовать образ старой ведьмы (злой и беспринципной учительницы) для сатирического представления атмосферы сдачи единого государственного экзамена (рис. 21, 22). Отметим, что в этой связи образ Бабы-Яги как мудрой старушки (дополнительно коррелирующий с экзаменатором ЕГЭ) способствует включению данного персонажа (а также соответствующего сказочного вербально-визуального контента) в различные дидактические проекты. Одним из показательных является цикл развивающих игр для детей дошкольного и младшего школьного возраста, разработанный группой МедиаХауз ${ }^{23}$ Баба-Яга в плену врага. Информатика; Баба-Яга за тридевять земель. Начинаем учить английский / немецкий / франиузский; Баба-Яга учится считать; Баба-Яга учится читать; Баба-Яга. Пойди туда, не знаю куда (развитие логического мышления); Баба-Яга. Школа на курьих ножках.

\section{Образ Бабы-Яги в маркетинговой сфере}

В русской культуре образ Бабы-Яги амбивалентен, в мифах и сказках она часто проявляет себя как знахарка, целительница, умудренная жизненным опы-

${ }^{23}$ МедиаХауз. [Online:] <http://www.mediahouse.ru/catalogue.html> (10.09.2017). 
том пожилая женщина, помогающая главному герою ${ }^{24}$. Эта сторона двойственной природы рассматриваемого персонажа способствует использованию образа Яги в маркетинговых целях. В России весьма продуктивной представляется эксплуатация образа Яги-ведуньи и травницы в медицинской сфере - не только при реализации всевозможных курсов автотренингов ${ }^{25}$, психотерапии семьи ${ }^{26}$, сайтов, толкующих о болезнях и их лечении ${ }^{27}$, но и прежде всего в рекламе натуральной косметики. Так, например, семантическая структура текста, рекламирующего российскую авторскую косметику «Яга», основана на апелляции к мудрости старой целительницы и секретам древних источников:

Косметика «ЯГА» - это реализация идеи, пришедшей как будто свыше и в то же время из глубокой древности. (...) Третий принцип, дошедший до нас из древних источников, заключается в отказе от деления базовой (недекоративной) косметики на дневную и ночную. (...) Наша кожа устала от равнодушной химической суспензии, в лучшем случае основанной на экстрактах, и обманчивых лифтингов. Реакция на полезные растения совсем иная. Это похоже на то, что сама Природа признается Женщине в любви ${ }^{28}$.

Е.А. Ноздренко и А.А. Ескина отмечают, что реклама как феномен современной культуры является «одним из показателей национальной индивидуальности и самости государства. В любой стране она должна обращаться к целевой аудитории на понятном ей языке. Соответственно, она использует легкочитаемые образы, символы, культурные традиции, те элементы, которые помогут потребителю идентифицировать себя с теми персонажами и ролями, которые предлагает ему реклама» ${ }^{29}$. А сказочные сюжеты, знакомые массовому потреби-

24 Такая трактовка образа хорошо вписывается в современную культурную парадигму и коррелирует с ипостасью Бабы-Яги, представленной в популярной русской песне Матушка Ягиня (2015), которую исполняют Татьяна и Андрей Шадровы ([Online:] <https://www. youtube.com/watch?v=n-20Ci-bhJg> (28.08.2017)):

Матушка Ягиня, древняя Богиня,

Добрая ведунья, бабушка-колдунья.

Сильь приумножит, хвори отворожит

и советом мудрым искренне поможет.

25 Чакра аджна - мудрость архетипа Бабы Яги. Какразвить видение и яснознание?. [Online:] $<$ https://samopoznanie.ru/articles/chakra_adzhna_-_mudrost_arhetipa_baby_yagi_kak_razvit_ viden/> (10.09.2017); Психологические мастерские Е. Литягиной. Женская психотерапевтическая группа «Баба Яга 2». [Online:] <https://samopoznanie.ru/trainings/zhenskiy_trening_baba_ yaga_otvetnyy_vizit/?date $=205575>(10.09 .2017)$.

26 П. Янг-Айзендрат. Ведьмы и герои: Феминистский подход к юнгенианской психотерапии семейных пар. Пер. В.К. Мершавка. Москва: Когито-Центр, 2005.

27 М. Норбеков, А. Алефиров. Как Баба-яга лечила свою костяную ногу, или Моя прабабушка дает советы. [Online:] <http://www.universalinternetlibrary.ru/book/10186/ogl.shtml\#t1> (10.09.2017).

28 Натуральная авторская косметика ручной работы. [Online:] <http://www.anapamama.ru/ news/2013/10/28/kosmetika-yaga-100-naturalnaya-avtorskaya-kosmetika-ruchnoi-raboty-v-magazine-olivko> (28.07.2017).

29 Е.А. Ноздренко, А.А. Ескина. Использование этнокультурных образов в отечественной рекламе как отражение культурных традиций. [Online:] <https://science-education.ru/ pdf/2013/6/417.pdf> (01.09.2017). 
телю услуг и товаров, оптимально позволяют моделировать поведение целевого адресата. В этой связи рекламное агентство Young \& Rubicam разработало рекламную кампанию для ипотечной линии банка ВТБ 24 под слоганом Om cкaзочных условий - $к$ реальным возможностям. Помимо телевизионной рекламы, кампания использовала такие каналы коммуникации, как печатная и наружная реклама, полиграфические материалы. Словесная метафора о сказочных услови$я x$, по мнению разработчиков, позволяет акцентировать внимание на потребителя на преимуществах продуктов ВТБ 24. Ролик выполнен в смешанной технике: его героями являются как анимационные, так и вполне реальные персонажи: главный герой - рисованный Федот (напоминающий Леонида Филатова, автора «Федота-стрельца»), его супруга - русская красавица Василиса Премудрая. Выйдя замуж, Василиса озаботилась проблемами благоустройства холостяцкой избы Федота и семейным бюджетом. Взяв ипотечный кредит ВТБ 24, молодожены зажили сказочно счастливо. О своей лояльности к клиентам банк напомнил в конце ролика, показав, что даже для Бабы-Яги может сделать сказку былью. В плакатах, напротив, ведунья Баба-Яга учит Федота житейской и банковской мудрости ${ }^{30}$.

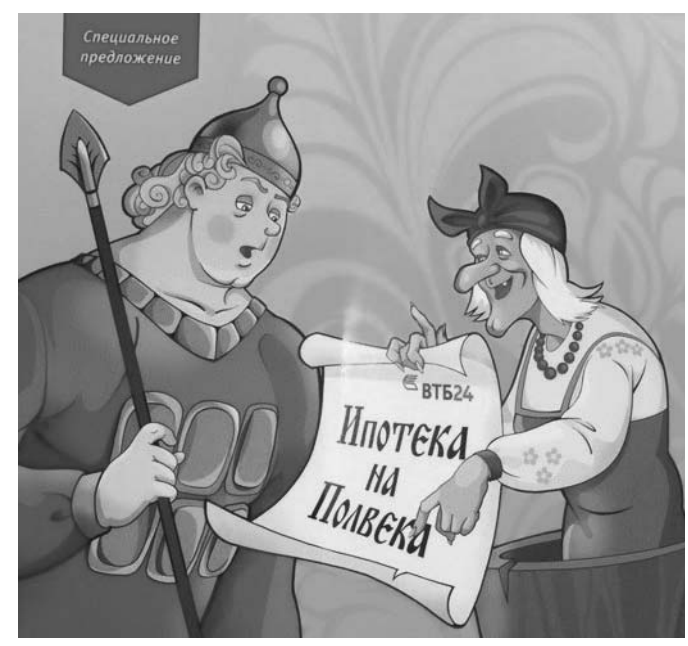

Рис. 23. Ипотека на полвека

Отметим, что создание рекламного сюжета, использующего прецедентные волшебные образы, требует мастерства и точности исполнения, в противном же случае ролик / плакат вызовет отторжение целевой аудитории или будет воспринят как пародия. Грамотно сказочные персонажи вписаны в стратегию коммерческой рекламы бренда «Причуда» - лидера рынка вафельных тортов в России. Ролик под слоганом Секрет внутри представляет собой экранизацию современного варианта сказки про Бабу-Ягу. Особенностью данного видеосообщения является то, что образы и характеры героев осовременены: Иван-Царевич переименован в Иван-007, у Бабы-Яги на входе в избушку уста-

30 Young \& Rubicam и ВТБ 24 делают сказку былью. Стрелеи, Федот и Василиса Премудрая начинают совместную жизнь с кредита. 2008. [Online: <http://www.sostav.ru/news/2008/04/24/ rol1/> (10.09.2017). 
новлен домофон, сама Яга значительно помолодела. Тем не менее композиция рекламного сюжета соответствует структуре сказки, в героях легко читаются известные сказочные персонажи. Иван-007 обращается за помощью к Бабе-Яге. Наскучил Василисе меч-леденец! - рассказывает ей Иван. На что Баба-Яга отвечает, что женщин нужно постоянно удивлять: В бисквите «Причуда», я спрятала сочность апельсинов под темным шоколадом. Иван-Царевич, как и в сказке, выполняет задание для завоевания сердца Василисы Премудрой, рискуя своей жизнью ${ }^{31}$. Несмотря на небольшую модификацию образов, они не утрачивают узнаваемости и ясны целевой аудитории.

Образ Бабы-Яги интенсивно используется в маркетинговой деятельности ресторанов, гостиниц, а также городской администрации с включением всей сказочной атрибутики - черный кот, избушка на курьих ножках, вороны, черепа: ресторан „Baba Jaga” во Вроцлаве; туристический старинный трамвай „Baba Jaga” 1925 года, курсирующий по Вроцлаву ${ }^{32}$; „Zajazd Baba Jaga” в Свентой Катажине (Święta Katarzyna); „Karczma Baba Jaga” в Радоме; „Gospoda u Baby Jagi” в Быдгощи; ресторан „Baba Yaga” в Москве, Тель-Авиве, Уфе, Перми; кафе «Баба Яга» в Самаре; кафе Бабы-Яги в Кукобое, где расположился ее музей. Примеры можно продолжать.

Дубравка Угрешич, хорватская писательница и автор искрометного романа о Бабе-Яге как квинтэссенции представлений о старой женщине, дает обзор широкому использованию образа Яги в коммерческой сфере:

...конечно, она не Опра Уинфри и не принцесса Диана, но, тем не менее, и не анонимный мифический персонаж. Ее имя носит центр шаманистики на севере Голландии, магазин настольных светильников где-то в Польше, польско-американский журнал („Baba Yaga’s Corner"), дом престарелых, семейный пансион и курсы иностранных языков в Германии. Имя Бабы Яги весьма популярно и у владельцев ресторанов, кондитерских и магазинов здоровых продуктов питания, что, учитывая гастрономические предпочтения этого персонажа, не лишено определенного юмора. Имеются фитнес-центры, носящие ее имя, видимо, потому, что их владельцы усматривают какую-то связь между Бабой Ягой и йогой?! «Баба Яга» - это и название немецкого производителя дамской одежды, и голландского спиритуального веб-сайта (где заинтересованные лица могут приобрести магические ведьмовские шары и чайники), и одного женского хора, тоже голландского. Образ Бабы Яги послужил источником вдохновения для некоторых театральных и музыкальных групп, художественных проектов, кинорежиссеров, авторов комиксов и мультипликационных фильмов, графических и неграфических книг, порносайтов и сайтов ужасов, блогов и реклам. Так, например, один сербский рекламный слоган для автомобиля порше „Carrera GT” звучит так: «Стремителен, как Баба Яга» ${ }^{33}$.

Подводя итоги, отметим, что рассмотренные в статье трансформации архитипичного образа Бабы-Яги обусловлены прагматикой современной комму-

31 Иван-007 и Баба-Яга продвигают «Причуду». 2005. [Online:] <http://www.shokoladka.ru/ news.php?n_id=1971> (10.09.2017).

32 Turystyczny tramwaj zabytkowy „Baba Jaga”. [Online:] <https://tramwaj-zabytkowy-po-wroclawiu.pl.tl/_--g-Baba-Jaga-g-.htm> (01.09.2017).

33 Д. Угрешич, Снесла Баба Яга яичко..., с. 318-319. 
никации, а также интерпретацией новых реалий окружающей действительности. В этом ракурсе можно переосмыслить известные слова Максима Горького о том, что «Люди знакомятся с новыми вещами, не только непосредственно видя и осязая вещи, но и по рассказам о вещах» ${ }^{34}$. Ключевые фигуры славянского божественного пантеона или славянской демонографии, к которым можно отнести Бабу-Ягу, являются базовыми концептами славянской культуры, характеризующимися многослойной семантической структурой. В этой связи они обладают колоссальным персуазивным потенциалом, позволяющим им участвовать в смыслообразовании политических, рекламных, дидактических, сатирических текстов.

\section{Литература}

Legendy Polskie. Film Jaga. Allegro. 2015. [Online:] <https://www.cda.pl/video/1169502e8> (01.09.2017).

Sładkiewicz Ż. Społeczeństwo „OKA” i tekst wielokodowy (na przykładzie rosyjskiej satyry politycznej). „Przegląd Rusycystyczny” 2014, № 3 (147), c. 111-124.

Winiarski D. Demony Leśne. Baba Jaga. [Online:] <https://slowianskibestiariusz.pl/bestiariusz/demony-lesne/baba-jaga/> (02.09.2017).

Young \& Rubicam и ВТБ 24 делают сказку былью. Стрелеи Федот и Василиса Премудрая начинают совместную жизнь с кредита. 2008. [Online:] <http://www.sostav.ru/ news/2008/04/24/rol1/> (10.09.2017).

Аникин В.П. К мудрости ступенька. О русских песнях, сказках, пословицах, загадках, народном языке. Очерки. Москва: Детская литература,1982.

Анисимова Е.Е. Паралингвистика и текст (к проблеме креолизованных и гибридных текстов). «Вопросы языкознания» 1992, № 1, с. 71-78.

Артемова Е.А. Карикатура как жанр политического дискурса. Диссертация на соискание научнй степени кандидата филологических наук. Волгоград 2002. [Online:] <http://dibase.ru/ article/05042010_artemova_evgenija_aleksandrovna_4478/1> (23.03.2017).

Баженова А. Солнечные боги славян. [Online:] <http://www.lomonosov.org/article/solar_gods_ slavs.htm> (10.09.2017).

Балушок В.Г. Инициаици древних славян. [Online:] <http://svitk.ru/004_book_book/1b/27_ baluhok-iniciacii_drevnih_slovyan.php> (06.09.2017).

Бернацкая А.А. К проблеме «креолизации» текста: история и современное состояние. «Речевое общение. Специализированный вестник». Ред. А.П. Сковородников, Вып. 3 (11). Красноярск 2000, с. 104-110.

Большакова Л.С. О содержании понятия «поликодовый текст». «Вестник СамГУ» 2008, № 4 (63), c. 19-24.

Ведчческий образ Бабы Яги. [Online:] <http://newcivilization.mirtesen.ru/blog/43840501133/ vedicheskiy-obraz-babyi-yagi> (01.09.2017).

Иван-007 и Баба-Яга продвигают «Причуду». 2005. [Online:] <http://www.shokoladka.ru/news. php?n_id=1971> (10.09.2017)

34 Цит. по: К.А. Лебедев. От составителя. [В:] Афганские сказки и тегенды. Пер. с пушту К.А. Лебедев, Москва: Наука, 1972, с. 6. 
Иванов В.В., Топоров Н.В. Баба Яга. [В:] Славянская мифология. Энииклопедический словарь. Москва: Эллис лак, 1995.

Ищук М.А. Гетерогенный текст: функиии его составляющих. «Вестник ТвГУ: Серия Филология». Выпуск: Лингвистика и межкультурная коммуникащия 2008, № 13, с. 176-182.

Караулов Ю.Н. Русский язык и языковая личность. Москва: Наука, 1987.

Кокорин В. Баба-Яга. [Online:] <https://sites.google.com/site/kokorinva/Home/b/baba-aga> (28.08.2017).

Куклина И.Н. Явления фразеологизации и дефразеологизащии в языке современной прессы. Диссертация на соискание научной степени кандидата филологических наук, Москва: МГОУ 2006.

Лебедев К.А. Афганские сказки и тегенды. Пер. с пушту К.А. Лебедев. Москва: Наука, 1972.

Ноздренко Е.А., Ескина А.А. Использование этнокультурных образов в отечественной рекламе как отражение культурных традиций. [Online:] <https://science-education.ru/ $\mathrm{pdf} / 2013 / 6 / 417 . p d f>(01.09 .2017)$.

Норбеков М., Алефиров А. Как Баба-яга течила свою костяную ногу, или Моя прабабушка дает советы. [Online:] <http://www.universalinternetlibrary.ru/book/10186/ogl.shtml\#t1> (10.09.2017).

Пономарева В. Обряд «перепекания» ребенка: на лопату и в печь. [Online:] <http://telo.by/ massage/obryad_perepekaniya_rebenka/> (09.09.2017).

Порозов Р.Ю. Визуальное как доминанта современной культуры. «Политическая лингвистика». Ред. А.П. Чудинов. Вып. 2 (36). Екатеринбург 2011, с. 219-222.

Пропп В.Я. Исторические корни волшебной сказки. Ред. и комм. И.В. Пешкова. Москва: Лабиринт, 2000.

Сорокин Ю.А., Тарасов Е.Ф. Креолизованные тексты и их коммуникативные функиии, [В:] Оптимизация речевого воздействия. Москва: Москва 1990, с. 180-186.

Степанов Ю.С. Константы: словарь русской культуры: опыт исследования. Москва: Школа «Языки русской культуры», 1997.

Угрешич Д. Снесла Баба Яга яичко. Пер. с серб-хорв. Л. Савельевой. Москва: Эксмо, 2011.

Фасмер М. Яга. [Online:] <https://vasmer.lexicography.online/\%D1\%8F/\%D1\%8F\%D0\%B3\%D0 $\% \mathrm{~B} 0>(04.09 .2017)$.

Чистякова Е.Е. Истоки происхождения образа Бабы Яги. 2017. [Online:] <https://nsportal.ru/ ap/library/literaturnoe-tvorchestvo/2017/04/29/istoki-proishozhdeniya-obraza-baby-yagi> (10.09.2017).

Янг-Айзендрат П. Ведьмы и герои: Феминистский подход к юнгенианской психотерапии семейных пар. Пер. В.К. Мершавка. Москва: Когито-Центр, 2005.

\section{Список источников $(\mathbf{1 0 . 0 9 . 2 0 1 7})^{35}$}

Рисунок 1. <https://durdom.in.ua/uk/main/photo/photo_id/23019/user_id/9509.phtml>

Рисунок 2. <http://posledniyrubezh.org/photos/photo654.html>

Рисунок 3. <http://fotki29.ru/photo_albums1399049705/political_humor/>

Рисунок 4. <http://likeness.ru/blog/topic/88282/dzhon_kerri_pokhozh_na_georgiya_millyara_v_ roli_babi_yagi.php>

35 Все иллюстрации скопированы с бесплатных общедоступных интернет-страниц либо сайтов, допускающих копирование со ссылкой на источник. Все иллюстрации приведены в тексте по принципу цитирования, без вмешательства в графическую структуру произведения. 
Рисунок 5. <http://volvo-sklad.ru/archives/1670>

Рисунок 6. <http://blog.liga.net/user/balashov/article/7028.aspx>

Рисунок 7. <http://contact.meta.ua/users/sergey-nepokupny-1301985/media/2207465.image>

Рисунок 8. <http://24today.net/open/486908>

Рисунок 9. <http://www.superdemotivator.ru/a-baba-yaga-protiv.html>

Рисунок 10. <https://durdom.in.ua/ru/main/photo/photo_id/11355/user_id/4363/filter/interesting/order/asc.phtml>

Рисунок 11. <http://xpomov.com/news/?page5>

Рисунок 12. <http://irina-wiki.pp.ua/novosti/pritcha-pro-babu-jagu.html>

Рисунок 13. <http://rem-tv.at.ua/photo/29-0-983>

Рисунок 14. <http://mif-vidar.narod.ru/smeh1.html>

Рисунок 15. <http://tomiks33.ru/upload/iblock/d0a/d0a9bfd40232616e0aac2ace50bca48e.JPG>

Рисунок 16. <http://tyum-pravda.ru/photos/25972-kran-works >

Рисунок 17. <http://dalance.ru/portfolio/alexgorec/25251/>

Рисунок 18. <http://forum.onliner.by/viewtopic.php?p=75826089\#p75826089>

Рисунок 19. <https://hodor.lol/post/82333/>

Рисунок 20. <https://patriotrus.ru/society/pensionnyie-mifyi-i-ix-sochiniteli.html >

Рисунок 21. <http://gmorder.livejournal.com/6186704.html?thread=120465360>

Рисунок 22. <http://unclepasha.net/wp-content/uploads/2015/06/ege1.jpg>

Рисунок 23. <http://www.hib.ru/2014/12/kredit-v-banke-ipoteka.html?m=0> 